\title{
THE HISTORY OF IDEAS REVISITED
}

In an essay entitled "Objectives and Methods in-Intellectual History ", published in 1957, I proposed that the field of study known as the history of ideas (often called intellectual history in the United States) be defined as a search for (a) the most general presuppositions of thought in a given age and (b) the factors responsible for bringing about changes in those presuppositions in the course of time '. By way of illustrating this approach to the history of ideas I undertook to delineate (1) what I conceived to be the dominant view of nature in the eighteenth century, (2) a formerly dominant but now (in the eighteenth century) subdominant view centered on the notion of decline from original perfection, and (3) an incipient view of nature as a law-bound system of matter in motion. I then tried to suggest some of the historical developments responsible for making the once-incipient view of nature the dominant view by the end of the nineteenth century. By that time the static view of nature as a framework of rationally contrived structures fitted as a stage for the activities of intelligent beings had been replaced by a view that represented all the structures of nature - stars, solar systems, mountain ranges, species, etc. - as products of the operations of a law-bound system of matter in motion; the only permanent structures were the atoms, the ultimate particles of the system of matter in motion.

As to the factors which helped to produce this change in presuppositions concerning nature, I suggested the following : (1) new discoveries in astronomy, geology, and paleontology suggesting that the seemingly permanent structures of nature might be more mutable than had been

1. John C. GreEnE, "Objectives and Methods in Intellectual History ", Mississippi Valley Historical Review, 4, 1957, p. 58-74. Reprinted in J. C. GREENE, Science, Ideology, and World View, Berkeley, University of California Press, 1981, p. 9-29.

Revue de synthèse : IVe $\mathrm{S} . \mathrm{N}^{\circ} 3$ juillet-septembre 1986. 
suspected, (2) the tendency of speculative thinkers like Descartes, Immanuel Kant, Erasmus Darwin, Laplace, and Lamarck to draw out the idea of universal mutability implicit in the mechanical view of nature by seeking to derive the present structures of nature from some previous, more homogeneous state of the system of matter in motion, (3) the use of the mechanical view of nature as an ideological weapon (by the philosophes and by Marx and Engels) in attacking the established institutions of society, (4) technological, social, economic, and political transformations accustoming the Western mind to the idea of constant change.

In short, I proposed a study of the interaction of science, ideology, and world view in modifying the general presuppositions of thought in the modern Western world, the basic idea being that in the short run the scientific enterprise was shaped and conditioned by prevailing general ideas about nature, science, man, and God but that in the long run scientific discoveries and theories altered these general ideas. In its first aspect, that of delineating the presuppositions of thought at given times, my conception resembled Michel Foucault's idea of an archaeology of ideas, but whereas Foucault offered no explanation whatever of the transition from one set of presuppositions to another in the course of history, I tried to suggest some of the influences involved, and I worked some of these out in my book The Death of Adam. Evolution and Its Impact on Western Thought (1959). In contrast to the Marxians, I did not suppose that science, ideology, and world view were all part of the ideological superstructure of capitalist society and hence determined in their nature by the capitalist mode of production. Instead, I viewed these three factors as interdependent variables interacting with each other and with other variables in Western civilization. Science I viewed as grounded partly in intellectual curiosity, the desire to know for the sake of knowing. Ideology I conceived as oriented toward programs of social action. World view I thought of as a set of assumptions (accompanied by feeling tone), sometimes explicit but generally implicit in figures of speech, concerning reality. Unlike Thomas Kuhn and Ernst Mayr, I did not believe that ideology and world view became less influential in scientific thought as the sciences became more " mature ". On the contrary, I suggested that this mode of analysis could be applied to twentieth century developments in science, although not without difficulties arising from the historian's immersion in twentieth-century thought.

So much for the schema set forth in 1957. What modifications and elaborations of it have subsequent years of research and reflection produced ? First, when I began to explore the origins of the dominant static view of nature and of the rival view of nature as a law-bound system 
of matter in motion, I discovered that each of them had a history reaching back to one or more schools of thought among the Greeks. The static view of nature and natural history presupposed by John Ray, Linnaeus, Cuvier, and others was essentially a Christianized Aristotelianism. The forms of the species, which for Aristotle were eternal, were now regarded as having been created " in the beginning "; in either case they remained stable and unchanged. The adaptation of structure to function and of organism to environment, which Aristotle attributed to nature's purposiveness, its immanent teleology, was now attributed to the wisdom of the Creator and hence regarded as absolutely perfect - something Aristotle had not claimed. Aristotelian logic dominated the taxonomic enterprise of naming, classifying, and describing the plants and animals of the world. Aristotle's physics and cosmology had been overthrown, but his biology persisted in a suitably Christianized form, not to be overthrown until Darwin published his Origin of Species.

As for the mechanical view of nature that replaced Aristotle's physics and cosmology, it was compounded of Christianized Platonism and Christianized atomism - a strange combination if there ever was one. The Bible contained no science, but it did contain the idea of an omnipotent, omniscient, benevolent Creator who had fashioned the material world and man in wisdom and who regarded his creation as good. The atomism of Leucippus and Democritus yielded little in the way of science because it postulated no ordering principle, but it contributed the atomic hypothesis and the doctrine of primary and secondary qualities. Plato's mathematicism, building on the Pythagorean idea that all things are made according to number and proportion, produced some excellent work in mathematics, optics, statics, and astronomy, but it was precluded from arriving at the idea of a general mathematical physics by its derogation of sense experience, its doctrine that material objects were but imperfect copies of ideas laid up in heaven, and its belief that the principle of reason in nature is not omnipotent.

The fusing of these quite disparate conceptions of nature required centuries. Some evidences of a Christianized Platonism were evident in the Middle Ages alongside the dominant Christianized Aristotelian physics and cosmology, but it was not until the seventeenth century that creationism and Platonism were united in the work of men like Kepler, Galileo, Descartes, and Newton. In Kepler's writings the PythagoreanPlatonic idea that mathematics is the key to understanding reality is presented in Christian terms : "... God, who founded everything in the world according to the norm of quantity, also has endowed man with 
a mind which can comprehend these norms ", Kepler wrote to Maestlin. "Those laws [which govern the material world] lie within the power of understanding of the human mind; God wanted us to perceive them when he created us in His image in order that we may take part in His own thoughts... " The mathematical harmonies in nature, said Kepler, are " not an image of the true pattern, but the true pattern itself " ${ }^{2}$. Thus, the marriage of Biblical creationism and Pythagorean mathematicism produced a world view in which a mathematical physics was not only possible but inevitable. Matter was no longer, as for Aristotle, an abstract capacity for taking on form. It was a concrete stuff created by God and structured and set in motion according to number and proportion.

Galileo, too, chose to conceive matter as a tangible stuff with mathematical properties imposed on it by the " divine Artificer ". He then went beyond Kepler in adopting the Atomists' distinction between primary and secondary qualities, stripping nature of all qualities but shape, size, motion, and other mathematical properties. Isaac Newton took the final step in fusing the Biblical with Platonic and Atomist world views when he speculated in the Optics that " God in the Beginning form'd Matter in solid, massy, hard, impenetrable, moveable Particles of such Sizes and Figures, and with such other Properties, and such Proportion to Space, as most conduced to the End for which he form'd them ${ }^{3}$.

It was Descartes, however, who grasped the implication of universal mutability implicit in the mechanical cosmology and proposed to derive the present structures of nature from previous states of the system of matter in motion by the operation of natural laws. Newton was horrified at this " mechanick theism " pretending to derive the present beautiful world from chaos by " a slight hypothesis of matter so and so mov'd ". He preferred to think that the same God who created the atoms of matter with their mathematical properties had ordered them in such a way as to produce the present universe. Newton's universe was no self-regulating, self-sufficient machine. God was ever active in it ; electricity, magnetism, gravitational force, and the like were modes of the divine activity. (In this view, Richard S. Westfall has suggested, Newton drew on the alchemical tradition ${ }^{4}$ ).

2. As quoted in Gerald HoltoN, « Johannes Kepler's Universe : Its Physics and Metaphysics ", American Journal of Physics, 24, 1956, p. 350. See also Winifred Lovell WISAN, « Galileo and God's Creation », Isis, vol. 77, sept. 1986.

3. Isaac Newton, Opticks..., London, 4th ed., 1730, p. 376.

4. Richard S. Westfall, Never at Rest : A Biography of Isaac Newton, New York, Cambridge University Press, 1980, p. 299 ff. 
Thus, the mechanical view of nature was not a monolithic, indivisible whole. Its component elements were fused in different ways by different seventeenth-century thinkers. In its Newtonian form, as in the Christianized Aristotelianism that prevailed in natural history, it was a highly static conception of nature linked to a static natural theology. In its Cartesian form, however, it was subversive of that static view and the accompanying argument from design. Newton's physics was destined to prevail over Cartesian physics in a relatively short time, but Descartes' project of deriving the present structures of nature from previous states of the law-bound system of matter in motion through the operation of natural laws was destined to bring about the eventual collapse of the static universe of Newton and John Ray.

The process of undermining and overthrowing the static view of nature and natural science was not a simple one, however. Within the static view itself some changes took place in the course of time, notably the emergence of a Platonic rival to the Christianized Aristotelianism of Linnaeus and Cuvier : namely, the Naturphilosophische conception of nature as a manifestation of Spirit or Idea - a rivalry dramatized in the famous debate between Cuvier and Étienne Geoffroy Saint-Hilaire in 1830. This rival view, derived from the philosophical idealism of Immanuel Kant and Friedrich Schelling, challenged the Aristotelian functionalism of Cuvier but not the underlying static view of nature and natural history. Nor was the gradual discovery of facts seemingly inconsistent with belief in the immutability of the structures of nature - e.g., organic remains of creatures not known to have living counterparts - sufficient to shake the hold of the static view. These discoveries could be explained away in one way or another, for example by postulating a series of successive creations to account for the succession of forms disclosed in the fossil record. Only when these anomalous facts were viewed with a Cartesian disposition to derive the existing structures of nature from the operations of a law-bound system of matter in motion did they become subversive of the static view of nature. The speculative temptation implicit in the mechanical cosmology led directly from Descartes to Buffon, Kant, and Laplace in astronomy, to the geological uniformitarianism of Hutton and Lyell, to the transformist ideas of Buffon, Erasmus Darwin, and Lamarck, and eventually to the all-embracing cosmic-biological-social evolutionism of Herbert Spencer. T. H. Huxley summed this development up succinctly when he laid it down as " the fundamental proposition of Evolution " that « the whole world, living and not living, is the result of the mutual interaction, according to definite laws, of the forces possessed by the molecules of which the primitive nebulosity of the universe was composed ", adding that this view was held in all its 
essentials by René Descartes, the spirit of whose Principles of Philosophy had been revived (said Huxley) in " the profound and vigourous writings of Mr. Spencer " ${ }^{5}$. What better evidence could a historian of ideas demand as evidence of the gradual replacement of the once-dominant static view of nature by the once-incipient mechanical view ? Indeed, Spencer declared his ultimate objective to be « the interpretation of all concrete phenomena in terms of the redistribution of matter and motion ". Robert Boyle's The Origin of Forms and Qualities, which explained the qualities of inorganic substances as resulting, not from their forms, but from a " concourse of accidents » in the atomic world, found its nineteenth-century counterpart in Charles Darwin's Origin of Species, a long essay on the origin of forms and qualities in the organic world. To a considerable extent Spencer, Darwin, and Huxley thought of themselves as simply extending to the world of life and history the conception of nature (now nature-history) as a law-bound system of matter in motion. The mechanical cosmology which had overthrown Aristotelian physics and cosmology in the seventeenth century had now overthrown the Christianized Aristotelianism of Linnaeus and Cuvier and the Christianized Platonism of Naturphilosophie as well !

A neat hypothesis, but things were not that simple. The extension of the mechanical view of nature to the realms of biology and history introduced ideas incompatible with that view, ideas capable ultimately of forming the basis of quite different views of nature. The first of these ideas was the idea of progress, the notion that the operation of the law-bound system of matter in motion could produce not only changes in the configurations of inorganic matter but also living organisms capable of evolving into higher and higher forms of life. But this notion of levels of being was foreign to the mechanical cosmology, which, as Alexandre Koyré observed, discarded " all considerations based upon value concepts ". But theories of evolution, from the time of Erasmus Darwin and Lamarck onward, incorporated the idea of progressive improvement, partly because the fossil record seemed to indicate that the "lower " forms of life had preceded the " higher " and partly because the growing belief in progress in the human world infected thinking about the natural world. From that time to the present day the idea of progress has played an incongruous and ambivalent role in evolutionary theory. Evolutionary biologists could not live with it because they could not define it without introducing value concepts prohibited by their idea of science.

5. Thomas Henry HuXley, « Evolution in Biology », in Darwiniana : Essays, New York, D. Appleton and Co., 1908, p. 206. This essay was first published in 1878 in the Encyclopaedia Britannica, 9th ed., Vill. 
But neither could they live without it, partly because the fossil record seemed to require it and partly because, as human beings, they needed to give meaning and value to the study of evolutionary biology.

Closely related to the idea of progress was a second idea equally incompatible with the mechanical view of nature, namely, the idea that mind is a part of nature. From Galileo onward nature had been conceived as a law-bound system of material particles possessing only mathematical properties such as size, shape, and motion. All other qualities - color, taste, sound, etc. - were " in the mind ", generated there by the impact of the particles of matter on the human sense organs. Mind and matter were totally incommensurable, said Descartes. The motions of matter could never produce mind. Yet this was exactly what evolutionary theory asserted : the motions of matter had given rise to one-celled organisms which, in their interactions with each other and with the inorganic environment, had evolved into thinking beings. Mind was now a part of nature, but nature was still conceived by Darwin, Spencer, and Huxley in terms of concepts derived from the mechanical cosmology of the seventeenth century. (Darwin repeatedly compared his theoretical achievement to Newton's, and Huxley, as we have seen, thought of his and Spencer's views as an extension of Cartesian ideas). Huxley might rhapsodize about « Nature's great progression from the formless to the formed - from blind force to conscious intellect and will $" 6$, but how was this possible ? Neither Newton nor Descartes would have been able to make any sense of such a progression.

A third evolutionary idea that fit badly with the mechanical view of nature and the conceptions of science associated with it was the idea of competitive struggle as the source of order, harmony, and progress in nature. This idea seems to have been peculiarly British and to have been closely linked to the development of British political economy and to the competitive ethos in British society. It was entirely foreign to the world view of Naturphilosophie - nature as a manifestation of Idea or Spirit - and equally incompatible with the French obsession with the problem of order posed by successive political revolutions. One can scarcely imagine August Comte, preoccupied as he was with this problem, suggesting competitive struggle as its solution. From Adam Smith onward, however, British thinkers were fascinated by the idea of competitive struggle. In Smith's The Wealth of Nations (1776) the idea appeared in its sunny, optimistic guise. The " system of natural liberty ", if left to operate according to the law of supply and demand, would insure, « as

6. ID., Man's Place in Nature and Other Anthropological Essays, New York, 1898, p. 151. 
if by a divine hand ", that everyone in the market place got his due as the wealth of nations increased. In Thomas Malthus' Essay on the Principle of Population (1798), however, the darker, pessimistic side of laissez-faire political economy became manifest. The tendency of human populations to increase geometrically produced a struggle for existence, especially among the laboring poor, driving wages down to the subsistence level, Malthus argued.

Given this view of things and British predominance in the rivalry of nation states for colonies and empire, it is not surprising that all of the thinkers who came forward with some idea of natural selection in the first six decades of the nineteenth century were British, mostly English. One thinks of William Wells, Patrick Matthew, Herbert Spencer, Charles Darwin, and Alfred Russel Wallace, all of whom had read Malthus' Essay and taken it seriously. British interest in overseas colonization and in scientific breeding of plants and animals also helped to produce theories of natural selection, and British natural theology enabled the men who produced these theories to view the competitive struggle as ultimately beneficial in its results. "As natural selection operates only by and for the good of each being ", wrote Charles Darwin, « all corporeal and mental endowments will tend to progress towards perfection "?

Closely linked to the idea of the beneficial effects of competition was another idea incongruous with the mechanical cosmology : the idea that chance plays an important part in nature. The essence of the law-bound system of matter in motion was that it was bound by natural laws to produce exactly what it did produce, so that, as $\mathrm{T}$. H. Huxley (drawing on Laplace) put it :

«... the existing world [we now behold] lay, potentially, in the cosmic vapour ; and... a sufficient intelligence could, from a knowledge of the properties of the molecules of that vapour, have predicted... the state of the Fauna of Britain in 1869 with as much certainty as one can say what will happen to the vapour of the breath on a cold winter's day $\$ 8$.

Darwin, too, thought that everything was governed by fixed laws " laws impressed on matter by the Creator " he called them in the Origin of Species - but his theory of natural selection was a probabilistic theory about the chances of survival and reproduction among organisms

7. Charles Darwin, On the Origin of Species..., Facsimile of the First Edition with an Introduction by Ernst MAYR, New York, Atheneum, 1967, p. 489.

8. T. H. HUXLEY, art. cit. supra n. 5, p. 206. 
varying at random with respect to their organic needs. The «laws » Darwin specified in the «Conclusion » to the Origin were processes rather than laws of nature in the traditional sense :

« These laws, taken in the largest sense, being Growth with Reproduction ; Inheritance which is almost implied by reproduction ; Variability from the indirect and direct action of the conditions of life, and from use and disuse ; a Ratio of Increase so high as to lead to a Struggle for Life, and as a consequence to Natural Selection, entailing Divergence of Character and the Extinction of less-improved forms. "

Darwin's theory, Charles S. Peirce noted, was simply « the consequence of a theorem in probabilities $"{ }^{9}$. Yet this essentially statistical process, devoid of any principle of order, was now called upon to account not only for the exquisite adaptation of organ to organ and of organism to environment but also for the gradual emergence of higher and higher levels of organization, mentality, and purpose in nature. The theory of natural selection purported to explain how functionally integrated organisms were modified by a process of differential survival and reproduction, but it offered no explanation as to how they came to be functionally integrated in the first place. This problem was pushed back into the evolutionary past in an infinite regress leading ultimately into the inorganic realms of nature.

Closely related to the conception of evolution as a statistical process was another idea equally difficult to reconcile with the mechanical cosmology - the idea of the uniqueness, the individuality, of every organism. The atoms and molecules of the physical sciences might have different properties depending on whether they were atoms or molecules of hydrogen or oxygen or copper, but the atoms or molecules of any given substance were thought of as essentially identical. Their individuality, if any, was negligible so far as science was concerned. But the organisms comprising a species of plant or animal were all different from each other in some respects, and it was these individual differences that determined the organism's chances of survival and reproduction and, concomitantly, the direction the course organic evolution would take ${ }^{10}$.

Thus, the triumph of the Cartesian program of deriving the present structures of nature from previous states of the law-bound system of matter in motion produced a world view containing ideas inconsistent

9. As quoted in Philip P. WIENER, Evolution and the Founders of Pragmatism, Cambridge, Harvard University Press, 1949, p. 81.

10. This line of argument is developed by E. MAYR in his Evolution and the Diversity of Life : Selected Essays, Cambridge, MA, Harvard University Press, 1976, chap. 6. 
with the mechanical cosmology that had helped to give it birth. These new ideas - progress and the concomitant idea of levels of being ; mind as a part of nature ; the functional unity and interdependence of organisms ; struggle, chance, and individuality as real factors in nature - rested in uneasy tension alongside conceptions of nature and natural science derived from seventeenth-century physical science. The tension was apparent in Darwin's oscillation between rejecting " necessary progression" in evolution and asserting natural improvement as a general consequence of natural selection; between discoursing about higher and lower organisms (including human races) and swearing never again to use the terms " higher" and "lower "; between viewing the course of evolution as entirely dependent on combinations of circumstances devoid of direction or aim and viewing it as the outcome of laws impressed on matter by the Creator insuring that in the long run all corporeal and mental endowments would tend to progress towards perfection ; between asserting that everything was governed by fixed laws and acknowledging that natural selection was a statistical process ; between emphasizing competitive struggle as the sine qua non of progress in nature and history and admiring the wonderful adaptedness and interdependence of organic beings ; between seeking to ground ethics and esthetics in natural and sexual selection and accepting Victorian standards of beauty, truth, and goodness as valid for mankind. Clearly the Darwinian world view, compounded of mechanistic determinism, belief in evolution by competitive struggle and survival of the fittest, and the idea of naturehistory as a single continuum undergoing progressive change in accordance with fixed laws discoverable by science, was not a seamless fabric fashioned for all time but an unstable compound of old and new ideas whose incompatibility must eventually become apparent with the progress of science and speculation.

As in the case of the Newtonian world view, however, the Darwinian world view required about seventy-five years to gain general acceptance in the scientific community and even then did so only in a modified form. Newton's law of universal gravitation and his conception of atoms moving in empty space under attractive and repulsive forces were not accepted by Continental scientists until the 1740 s and then only with important qualifications and additions borrowed from the Cartesian-HuygensianLeibnizian tradition. So, too, with Darwinism. The idea of organic evolution (which was not original with Darwin) caught on rapidly after the publication of the Origin of Species, but the Darwin-Wallace theory of natural selection as the "mechanism " of evolution found no widespread acceptance among biologists before 1930. Evolutionary theories invoking Lamarckian and neo-Lamarckian factors, « mutation 
pressure ", and the like proliferated until, in the 1930s and 1940s, the protagonists of the "modern synthesis " made the theory of natural selection the centerpiece in their synthesis of the results of several decades of research in genetics, paleontology, and systematics. Only then can a truly Darwinian evolutionary biology and world view be said to have emerged triumphant.

On the scientific battlefield the chief enemy of the champions of the modern synthesis was not static creationism, as it had been for Darwin, but rather various forms of evolutionary theory that postulated some directive principle or tendency in nature other than natural selection. In some respects the arguments were purely scientific. Was the inheritance of characters acquired during the life of an organism scientifically credible ? Could a series of mutations in a given direction produce a new species without the aid of natural selection ? In other respects, however, the attack on theories of orthogenesis, nomogenesis, aristogenesis, and neo-Lamarckianism incorporated elements of world view. These theories were rejected as " metaphysical " resurgences of vitalism and finalism, as unscientific ideologies incompatible with a truly scientific and mechanistic view of evolution.

These elements of world view came to the surface prominently in the book which gave the modern synthesis its name : Julian Huxley's Evolution : The Modern Synthesis (1943). Huxley's preoccupation with the philosophical and ideological aspects of evolutionary theory was apparent in the preface. This book, Huxley explained, grew out of his presidential address before the Zoology Section of the British Association for the Advancement of Science entitled "Natural Selection and Evolutionary Progress". The book, an expanded version of this lecture, professed a double purpose : (1) to show that the theory of natural selection, revised in the light of discoveries in genetics, could provide the centerpiece for a unified biological outlook, and (2) to vindicate the idea of evolutionary progress. The first eight chapters, devoted almost entirely to organic modification at or below the species level, were designed to achieve the first of these objectives ; the last two chapters, "Evolutionary Trends" and "Evolutionary Progress ", fulfilled the second objective. But the closing pages of the work disclosed even wider purposes. The idea of progress was to be vindicated against its disillusioned early twentiethcentury critics by proving progress to be a general aspect of naturehistory and a phenomenon dependent (at the human level) on human effort, not on " mythical gods or metaphysical absolutes ». Finally, the analysis of evolutionary progress would shed light on the struggle between totalitarianism and democracy : « two opposed ideals - that 
of the subordination of the individual to the community, and that of his intrinsic superiority " ".

Even in the chapters devoted to describing evolution at or below the species level Huxley's predominant concern with evolutionary progress (" the process by which the utilization of the earth's resources by living matter is rendered progressively more efficient ") was evident. Although he devoted much space to the various processes involved in the production of " minor systematic diversity ", he viewed these processes as « the consequences of accidents in the environment or in the genetic machinery of life " and as having " little or no bearing " on long range trends. " Much of the minor systematic diversity to be observed in nature ", he wrote, « is irrelevant to the main course of evolution, a mere frill of variety superimposed upon its broad pattern $"{ }^{12}$. Although the biologist must try to explain organic modification (" evolutiòn ") in all its varied forms, his main concern, said Huxley, must be to discover the " broad pattern " of evolutionary development and to elaborate its significance for the future history of mankind.

Huxley's distinction between " mere change and diversification " and " evolutionary progress", between the " accidents " of evolution and its " main course », raised interesting and difficult problems. How was the biologist to determine which organic changes were accidental and which essential or progressive ? Were not the processes that produced minor systematic diversity the same as those responsible for the broad pattern of evolutionary development ? Was not Huxley's distinction a purely subjective one dictated by his determination to display human progress as " a special case of biological progress "?

The problems implicit in attempting to make the idea of progress central in an evolutionary theory professing to be "naturalistic " and " mechanistic " became even more evident in the chapter entitled "Evolutionary Progress ". Huxley agreed with Darwin that progress or improvement (Darwin's term) was an essential aspect of evolution by natural selection, though not its necessary result in any particular case. Progress was not « universal and compulsory " (Huxley), there was no " necessary progression " (Darwin), but in the long run evolution by natural selection was progressive. But here the resemblance between the two men's ideas about progress ended. For Victorians like Darwin progress was something to be taken for granted; for Julian Huxley it

11. Julian Huxley, Evolution : the Modern Synthesis, New York, Harper \& Bros., 1943, p. 577-578.

12. Jbid., p. 389. 
was an idea to be vindicated against twentieth-century sceptics. Darwin seems to have derived the idea of evolutionary improvement partly from nineteenth-century optimism, partly from the analogy to improvements produced by plant and animal breeders, but even more from the theory of natural selection :

" As each species is improved, and as the number of forms will have increased [he explained to Lyell], if we look to the whole course of time, the organic condition of life for other forms will have become more complex, and there will be a necessity for other forms to become improved or they will be exterminated; and I can see no limit to this process of improvement, without the intervention of any other and direct principle of improvement. All this seems to me quite compatible with certain forms fitted for simple conditions remaining unaltered, or being degraded.

If I have a second edition, I will reiterate 'Natural Selection', and, as a general consequence, Natural Improvement $" 13$.

For Julian Huxley, however, the proof of progress had to be inductive, based on the fossil record. That record, said Huxley, disclosed a succession of dominant forms some of which were regarded by biologists as " higher " than others, however difficult they might find it to explain what they meant by " higher ». Accepting this intuitive judgment, Huxley looked for a common denominator in the traits possessed by organisms considered to be " higher ". He found it in their increased biological efficiency, defined as "increased control over and independence of the environment". If, then, as Huxley thought, one could discern a succession of dominant forms displaying these kinds of increased biological efficiency, progress was shown to be an aspect of organic evolution in the long run.

Thus, whereas Darwin regarded progress as a necessary implication of the theory of natural selection Huxley grounded it in the fossil record - « the historical fact of a succession of dominant groups " without reference to selection. It is not surprising, then, that the two men had very different feelings about the process of natural selection. In the Origin Darwin seems to have viewed natural selection as the means by which the Creator was bringing about adaptation and improvement in the organic world. Natural selection was

13. Letter from Charles Darwin to Charles Lyell, Ilkley, Yorkshire, October 25, 1859, quoted in The Life and Letters of Charles Darwin Including an Autobiographical Chapter, Francis DaRwiN, ed., 3 vols, New York, 1898, t. I, p. 531. 
" daily and hourly scrutinising, throughout the world, every variation, even the slightest ; rejecting that which is bad, preserving all that is good ; silently and insensibly working, whenever and wherever opportunity offers, at the improvement of each organic being in relation to its organic and inorganic conditions of life $\gg 14$.

Huxley agreed that natural selection was the chief cause of adaptation in nature, but he put no such optimistic, theistic interpretation on the process. Natural selection, he wrote, « does not ensure progress, or maximum advantage, or any other ideal state of affairs. All that natural selection can ensure is survival ». Biologists, he said, must give up the idea

" that natural selection and the adaptations that it promotes must be for the good of the species as a whole, for the good of the evolving type pursuing a long-range trend, for the good of the group undergoing adaptive radiation, or even that it must promote constant evolutionary progress $\$ 15$.

Indeed, Huxley joined with J. B. S. Haldane in asserting that intraspecific selection, which Darwin regarded as the primary engine of organic improvement, was « on the whole a biological evil ». (Haldane analogized intraspecific competition to competition in armaments, subsidies, and tariffs, which [he said] « absorb a proportion of the national wealth which many believe might be better employed »).

" Natural selection ", added Huxley, " though... like the mills of God in grinding slowly and grinding small, has few other attributes that a civilized religion would call Divine. It is efficient in its way - at the price of extreme slowness and extreme cruelty. But it is blind and mechanical ; and accordingly its products are just as likely to be aesthetically, morally, or intellectually repulsive to us as they are to be attractive $" 16$.

In this passage Huxley echoed the darker reflections of Darwin on " the clumsy, wasteful, blundering, low, and horribly cruel works of nature " ! Huxley's ideological intent became clear when he concluded that he had disposed of the idea, "so assiduously rationalized by the militarists in one way and by the laissez-faire economists in another, that all man need do to achieve further progressive evolution is to adopt the most thoroughgoing competition ". A far cry this from

14. C. DARWIN, op. cit. supra n. 7, p. 84.

15. J. HUXLEY, op. cit. supra n. 11, p. 483-485. See in this connection Howard L. KAYE, The Social Meaning of Modern Biology : From Social Darwinism to Sociobiology, New Haven, Yale University Press, 1986.

16. Ibid., p. 485. 
Darwin's faith in competitive struggle as an engine of progress in nature-history !

Despite his distaste for the process of natural selection, Huxley was forced to rely on it as the main agent of evolutionary change, partly because he could not admit habit, use, and disuse into his evolutionary picture (as Darwin did) but even more because of his insistence that the agents of change must be " mechanistic ". Theism, vitalism, and finalism must be expelled from evolutionary theory. At the same time, however, Huxley was concerned to refute the arguments of " certain laboratory mechanists " who were disposed to deny or ignore the fact of adaptation on the ground that it smacked of teleology and interfered with scientific analysis on " good mechanistic principles ". How, then, was he to avoid the Scylla of finalism and vitalism without steering into the Charybdis of a mechanistic determinism that reduced biology to physics and chemistry?

Huxley's strategy in this dilemma was relatively simple. Against the laboratory mechanists he stressed the patent fact of the adaptation of structure to function, of organism to environment, giving abundant examples of the same. Against the theists, vitalists, and finalists he argued that the purposiveness of these adaptations was only apparent ; they were the result, not of some purposive agent inside or outside of nature, but of natural selection, a good Darwinian « mechanistic " process. Once the biologist had recognized « the constant correspondence between structure and inborn behaviour on the one hand and environment and way of life on the other ", he must believe " either in purposive creation or in adaptive evolution ", and Huxiey was prepared to show that the believer in adaptive evolution could do without the idea of a Purposer but not without the idea of progress ${ }^{17}$.

In Huxley's view, adaptation was just another name for functional efficiency - " functional efficiency seen from a slightly different angle ". From this point of view the main evolutionary process, " adaptive evolution ", was the process by which the biological machinery of organisms - the machinery of assimilation, reproduction, reactivity, etc. - was gradually improved. Any of these functions could be " specialized or improved in various ways during evolution to meet the needs of the organism $"$. Adaptation through natural selection would produce "basic improvements in organic mechanism ". Particular species or lineages might become extinct through excessive adaptive specialization to particular environments, but some "biological

17. Ibid., p. 413. 
inventions " - internal temperature regulation, lungs, the cleidoic shelled egg, etc. - would increase the all-round biological efficiency of living matter and thereby carry life to new levels of organization conferring ever-increasing control of and independence of the environment:

Thus, whereas Darwin had analogized the improvement effected by natural selection to the improvement accomplished by the plant and animal breeder, Huxley adopted figures of speech borrowed from the efficiency engineers of the twentieth century. Instead of personifying natural selection as the agent of improvement in nature he personified life, "living matter ", as the hero of the evolutionary epic and viewed evolutionary progress as improvement in the efficiency of "living in general ". These were highly anthropomorphic, teleological figures of speech, but Huxley was insistent that evolutionary improvements in biological efficiency were the outcome of the "blind, mechanical " process of natural selection. To explain them in terms of Lamarckism or orthogenesis would be to open the door to vitalism and mysticism.

Huxley had to concede, however, that natural selection was a very sloppy engineer. Perfection of adaptation depended on the degree of selective pressure. Organisms were selected « not in relation to complete functional efficiency, but on the basis of survival ", and survival might be achieved by means of " curiously makeshift devices ". Both specialized and progressive improvements in biological machinery were " mere by-products " of natural selection, " the exceptions rather than the rule ". It followed, said Huxley, that the militarists and the laissezfaire economists were entirely wrong in urging competitive struggle as prerequisite for further progress in human affairs. Once evolution had produced thinking, purposive beings, it was their responsibility to direct the future course of evolution in a more efficient way by developing « a rational applied biology $1{ }^{18}$.

In the end Huxley found himself in a dilemma generated by his determination to ban teleology from nature. Against the theists, finalists, and vitalists he argued for a naturalistic and mechanistic view of evolution. But such a view of nature had no room for notions of " higher " and " lower ", of " progress ", " stagnation ", or " retrogression " in evolution, or for distinctions between " mere evolutionary change " and " progressive " change. Nature's machine produced what it had to produce. To call its products " higher " or «lower ", its processes cruel, wasteful, and blundering, was to introduce human

18. Ibid., p. 485 . 
standards of value into nature and, by implication, to deny that human beings were totally a part of nature, since they could stand in judgment on nature's processes. To set up a dichotomy between living matter and its environment, representing life as " exploiting " the environment and gaining independence and control of it, was to abandon the mechanistic view of nature and embrace a cryptic vitalism that pitted life against inanimate nature.

Huxley must have felt the force of this logic, yet as a naturalist he could not ignore the fact of adaptation, of the harmony of organic beings both internally and with respect to their environing circumstances, nor could he deny his intuitive appreciation of different levels of being in the organic world, levels which seemed to have arisen successively in the course of evolution. But how could he reconcile these facts and intuitions with the mechanistic view of nature he had come to regard as essential not only for sound science but even more for the rational conduct of life ? Huxley's solution to this dilemma was, on the one hand, to insist on natural selection as a sufficient mechanistic process to account for major trends in evolution and, on the other, to portray those trends in figures of speech borrowed from the progress of human technology. In doing so, however, he fell into an implicit vitalism and teleology and undermined the idea that human beings are part of nature in every aspect of their being.

With regard to man, Huxley was in the difficult position of arguing that evolution gave mankind guidance and inspiration with respect to the long-run direction of change but, at the same time, that its processes of random variation and competitive struggle for existence were not to be taken as models for future evolutionary development. Human technological progress became Huxley's model of organic evolution : life was achieving ever increasing control and independence of the environment through improvements in the efficiency of biological machinery. Given these criteria of progress, it is not surprising that Huxley regarded man as the highest product of evolution, "business manager for the cosmic process of evolution ", as he said in Evolution in Action (1953). Until the appearance of human beings, said Huxley, nature knew only the " biological values " of survival and reproduction, of control and independence of the environment. With man's appearance a broad array of new values emerged, but these new values - intellectual and esthetic satisfaction, "mystic detachment and inner ecstasy ", and the like were ideal possibilities of human nature, not attributes of life generally. And even at the biological level the future was wide open : nature had produced a being who not only comprehended nature but had the power to alter his own nature by eugenic experimentation and control. 
Obviously the concept of "nature " had been strained beyond recognition. For Spencer and Darwin nature-history was a single continuum subject to fixed laws of development ; social evolution was a continuation of organic evolution, although subject to human " interference " in its course. For Julian Huxley, however, nature had become « a one-way process in time ; unitary, continuous, irreversible ; self-transforming; and generating variety and novelty during its transformations ", a process involving " the replacement of old types by new, the emergence and gradual liberation of mind, the narrow and winding stairway of progress, and the steady advance of life up its steps of novelty "19. Mind, which Descartes had declared to be totally incommensurable with matter, was now conceived as an aspect of a " world substance " possessing mind-like properties in all its forms. And evolution, although described as "mechanistic", was basically an " over-all process of realizing new possibilities of variety and organization ". But it had no telos until human beings appeared to give it aim and purpose both retrospectively and in the future. Anthropocentrism, which was thought to have been exorcised from science by the combined efforts of Copernicus, Lyell, and Darwin, was once more in the driver's seat. The fate not only of mankind but also of life on the planet Earth and (if Huxley was right) of the cosmic process of evolution was now seen to depend, not on the impersonal operation of fixed laws of naturehistory, but on human decisions for good or ill.

Huxley's writings display in bold relief the tensions, contradictions, and ambivalences of twentieth-century Darwinism and the interaction of science, ideology, and world view in the formation of the " modern synthesis ". If space permitted, it would be possible to illustrate this interaction from the writings of other architects of the synthesis : for example, Ernst Mayr, George Gaylord Simpson, and G. Ledyard Stebbins. It must suffice, however, to indicate the general nature of the presuppositions, attitudes, and polemical positions they shared with Julian Huxley. As scientists, all of these men except Simpson, a paleontologist, were primarily concerned with evolution at or below the species level, with " microevolution ". But as philosophical biologists, as members of the human community concerned with political and social issues, as individuals seeking to find meaning and value in their scientific work, they looked to evolution on the grand scale for answers to the age-old problem of human duty and destiny, answers grounded in ideas of nature, man, science, society, and history. For this purpose microevolution

19. J. HuXLeY, Evolution in Action, New York, New American Library, 1953, p. 28. 
was of little use. One must grasp the broad outlines of the evolution of life on earth, discover the processes that had generated and shaped it, and draw lessons from it concerning human nature, duty, and destiny.

It turned out, however, that the lessons to be drawn were prescribed in advance by preconceived ideas concerning nature, science, man, and reality in general. Ontologically, nominalism was prescribed : " only individual phenomena have reality. " Epistemologically the outlook was positivistic, opposed to " any mixing of philosophy and science " and dismissing vitalism and finalism as « nonscientific ideologies " involving " unverifiable theological or metaphysical doctrines ". Scientific explanations must be mechanistic and causal. Teleological explanations were rejected as " non-causal "; causes must be " material " and " not in the future $"{ }^{20}$. On these grounds not only static and evolutionary creationism but also neo-Lamarckianism, orthogenesis, nomogenesis, aristogenesis, and the like were dismissed as unscientific.

Unfortunately, these mechanistic and positivistic maxims, however useful they might be in refuting creationists, finalists, and vitalists, became an embarrassment when the champions of the modern synthesis turned to meet challenges from the advocates of mutation pressure, neutralism, and molecular genetics. Against these " laboratory mechanists " the field naturalists who constructed the modern synthesis adopted a very different line of argument. Evolutionary biology, said Ernst Mayr, was "more like archeology and linguistics than like physics ". Computer simulations of evolutionary processes were invalid because biological organisms, unlike atoms and molecules, were unique. For that reason the study of evolution could not yield general laws but only generalizations possessing statistical validity. Evolutionary biology was « incurably historical ". Prediction was difficult in both microevolution and macroevolution, and causal explanations of past biological events were often "unspecific and purely formal». Above all, living things possessed a quasi-teleological functional unity; their activities were " goal-directed " 2 .

Obviously this line of argument, if pressed to its logical conclusion, would undermine the positivistic, mechanistic critique of creationism, finalism, and vitalism essential to the new brand of Darwinism. Somehow or other the " overall harmony of the organic world " and the " perfection of adaptation " in that world must be explained without

20. E. MAYR, op. cit. supra n. 10, passim. See also George Gaylord SIMPSON, This View of Life. The World of an Evolutionist, New York, Harcourt Brace, 1964, Part III.

21. E. MAYr, op. cit. supra n. 10, Part IV. 
recourse to any " outside agency » or any inner perfecting principle in nature. The apparent purposiveness and goal-directedness of organisms must be shown to be an illusion explicable on " good mechanistic principles ». To this end a distinction was made between old-fashioned Aristotelian teleology on the one hand and teleonomy, or « mechanistic purposiveness $"$, on the other. A suitable analogy and terminology for this non-teleological teleology was eventually discovered in " new concepts from the fields of cybernetics and new terminologies from the language of information theory ". Like a computer, wrote Ernst Mayr, organisms were programmed (in the DNA) to perform goal-directed activities. The program, moreover, was « something material », existing prior to the initiation of the teleonomic process (ontogeny), hence it was « consistent with a causal explanation ". The DNA, it turned out, was a material embodiment of Aristotle's Unmoved Mover! It initiated and controlled goal-directed activities without being affected in any way itself 22 .

"Mechanistic » here meant " like a machine ", more especially like a computer or computerized robot. But a machine is a human artifact made for a specific purpose. The " information " in the " blueprint " of the computer is put into the computer program by an intelligent being for a definite purpose. Mayr's language about information, instructions, translation of the blueprint (like an orchestra conductor interpreting a musical score and directing the players to produce certain sounds repressor and inducer genes playing the role of the conductor) was highly anthropomorphic, projecting on to a nonhuman process the technological aims and terminology of human engineering. Aristotle's problem of the teleological aspect of living things had not been solved but only rephrased in computer jargon.

Passing from functional biology to evolutionary biology, the champions of the modern synthesis again occupied a polemical position midway between the reductionists and the vitalists-finalists. Against the latter they argued that, although the activities and functions of organisms were goal-directed (teleonomic), evolutionary developments were not. Species populations and evolutionary lineages could not act purposively. The seemingly goal-directed character of progressive evolutionary adaptation was the outcome of a combination of chance and anti-chance processes, both of which were « mechanistic ». But when the advocates of the new synthesis turned to describing the process of evolution by natural selection, they used language that implied teleonomy if not

22. Ibid., chap. 26. See also, p. $42-43$. 
outright teleology. The "real function " of mutation, wrote Ernst Mayr, was the replenishment of the gene pool. The "function" of isolating mechanisms was " to prevent interspecific courtship ". Reproductive isolation was a "method guaranteeing evolutionary success ". Biological species were "invented " in the course of evolution as a "method" of preventing unsuccessful gene combinations from occurring. Natural selection, although a «purely statistical phenomenon " without any aim, could nevertheless improve adaptation continually until it appeared " as perfect as if it were the product of design ". It could " remodel proteins in order to improve interactions " and " give direction » to evolution. It produced " ever increasing improvements in mechanical efficiency". It " did its best " to favor the production of programs « guaranteeing behavior that increases fitness". But it could "fail " when the "right genes " were not available for selection. Extinction was a " failure of natural selection ". (But how could a process that had no aim or purpose fail ?) Apparently Mayr was torn between his admiration for the wonderful work of natural selection in producing ever increasing adaptation, efficiency, and improvement and his concern lest these results be taken as proofs of the designing intent of some " outside agency ${ }^{23}$.

Like Julian Huxley, Mayr distinguished between « mere evolutionary change " and progressive changes involving « qualitative improvement of genetic and biochemical systems ". The " final product " of evolution, Mayr asserted, was "perfection in adaptation ", but were the latest products of evolution any better adapted to their environments than the earlier ones? Was the modern horse better adapted to its environment than eohippus was to its environment? (Or modern man to his than Aurignacian man to his ?) Fitness, or " selective value ", was said to be composed of two elements : " adaptive superiority " and " reproductive success ". But how could one judge whether certain members of a population had adaptive superiority except by their reproductive success ? Mayr offered an « operational definition " of selective superiority in terms of « the contribution to the gene pool of the next generation ». But he then confounded the argument by stating that in the case of human beings "genuine adaptedness" was separated from "mere reproductive success $"{ }^{24}$. The distinction implied some criterion of adaptive superiority other than reproductive success, but Mayr never indicated what it was.

23. Ibid., Part I, p. 17, 19, 34, 39, 42, 66, 70, 89, 93, 95, 104-106.

24. Ibid., p. $25,29,34$. 
Again like Huxley, Mayr analogized improvements in organisms to improvements in the motor car, projecting technological language onto the evolutionary process and thereby introducing a cryptic teleology into the description of evolution. Progressive evolution (one of Mayr's four types of evolution) was said to produce " ever-increasing improvements in mechanical efficiency ", but efficiency is always defined with respect to some end. What end? Survival and reproduction? Qualitative improvement ? The efforts of living matter to " exploit " the environment ? In a truly mechanistic view of nature there are no ends. There are only effects, such as survival and reproduction or non-survival and nonreproduction. Nor is there any room for " qualitative improvements " of any kind. Human beings may feel that certain products of evolutionary processes are " higher " and " better " than others, but evolutionary biology in the "mechanistic " Darwinian context has no criteria for making such qualitative judgments. The mechanistic world view, as Alexandre Koyré observed, involved

" the discarding by scientific thought of all considerations based upon value concepts, such as perfection, harmony, meaning and aim, and finally the utter devalorization of being, the divorce of the world of value from the world of facts $»{ }^{25}$.

But Mayr and Huxley and the other founders of the modern synthesis refused to live in a world stripped of meaning, harmony, perfection, and value. As field naturalists they were keenly aware of the harmony of living things, of the perfection of adaptation, of the qualitative differences between the life of an amoeba and the life of a human being. They had to make room for these intuitions, and if the conception of nature and natural science in which they were reared left no such room, simile and metaphor must be called upon to give evolutionary biology a meaning and value that could not be supplied by the positivistic, mechanistic conceptual framework of neo-Darwinism.

By the mid-twentieth century, then, important changes had taken place in the Darwinian world view. Natural selection continued to be regarded as the primary agent of both microevolution and macroevolution, but it was now conceived statistically rather than as a competitive struggle for existence. Such a struggle seemed less admirable and hopeful, after two world wars and the horrors of the Nazi death camps, than it had in Darwin's time. As for the idea of progress, it continued to play a

25. Alexandre KOYRÉ, From the Closed World to the Infinite Universe, Baltimore, Johns Hopkins University Press, 1957, p. 2. 
highly ambivalent role in Darwinist biology. Efforts to define progress scientifically and prove its existence from the fossil record found little support within the scientific community, yet the idea kept cropping up again and again in the language biologists used to describe evolutionary processes, and always with the tacit assumption that human beings were the highest product of those processes. Man was still regarded as a purely natural being, but the effort to conflate nature and human history in a single continuum governed by natural laws foundered on the growing realization that the future course of evolution on the planet Earth depended primarily, not on the impersonal operation of laws of nature-history, but on human choices dictated by value attitudes foreign to nature and by visions of the ideal possibilities of human nature. Despite the effort to sink man into nature and explode his pretensions to a special status, the evolutionary picture became more and more anthropocentric.

Indeed, the concept of nature presupposed by Darwin and his contemporaries was disintegrating. At the level of physical research the mechanical world view lay in ruins. Heisenberg's principle of indeterminacy gave the coup de grâce to T. H. Huxley's vision of Evolution unrolling ineluctably from the properties characterizing the molecules composing the primitive nebulosity of the universe. Statistical mechanics showed that the so-called laws of nature were merely condensed descriptions of how things were observed to behave, no different in kind from statistical generalizations concerning human behavior. Atomic research exploded Newton's Christianized atomism; the atoms were not only divisible but generable and dissoluble. Quantum mechanics shattered what was left of the mechanistic universe, posing baffling problems concerning the ultimate nature of reality.

Meanwhile the champions of the modern synthesis, although they continued to invoke the mechanistic and positivistic maxims of nineteenth-century physics against creationists, finalists, and vitalists, began at the same time to reject the philosophy of science associated with modern physics as adequate or normative for biology, stressing the uniqueness and functional unity of organisms, the presence of levels of integration in nature, and the "incurably historical " character of evolution. Physicists, wrote George Gaylord Simpson, seek to find principles of increasing generality applicable to all material processes, but this leads them to falsify nature and ignore the complexity of living things. It would be better, said Simpson, to unify the sciences by studying phenomena to which all principles, not just the principles of physics, apply. It would then be seen that 
biology, not physics, was « the science that stands at the center of all science $"{ }^{26}$.

Other advocates of the modern synthesis, wrestling with the problems raised by sinking man into nature and thus making mind a part of nature, were driven to various forms of panpsychism, as may be seen from the essays by Bernard Rensch and Sewall Wright in Mind in Nature and from Julian Huxley's Evolution in Action. Sewall Wright wrote :

« Emergence of mind from no mind at all is sheer magic. We conclude that the evolution of mind must have been coextensive with the evolution of the body. Moreover, mind must already have been there when life arose and indeed must be a universal aspect of existence. "

\section{Again :}

« Reality clearly consists primarily of streams of consciousness. This fact must take precedence over the laws of nature of physical science in arriving at a unified philosopy of science, even though it must be largely ignored in science itself $\gg 27$.

But instead of contrasting the uniqueness and hierarchic structure of organisms with the homogeneity and lack of hierarchic structure in atoms and molecules (as Ernst Mayr did) Wright found individuality and hierarchic structure throughout nature.

« The crucial point was that a living organism is more comparable to a molecule or atom among inanimate things than to a mere unorganized aggregation of materials like a stone. Conversely a molecule or atom might seem much like a little organism if we could observe the incessant activity which the physical scientists now attribute to them $"{ }^{28}$.

Meanwhile the concepts of nature and science taken for granted by the champions of the modern synthesis were subject to increasing attack within the biological community. On the one hand, structuralist biologists like A. J. Hughes and D. M. Lambert assailed the functionalism and reductionism of neo-Darwinian evolutionary theory, resurrecting Étienne Geoffroy Saint-Hilaire's call for « a pure morphology uncontaminated by functional considerations $»$ and rejecting the neo-Darwinian

26. G. SIMPSON, op. cit. supra n. 20, p. 107.

27. Sewall Wright, Mind in Nature : Essays on the Interface of Science and Philosophy, Washington, University Press of America, 1977, « Panpsychism and Science », p. 82.

28. Ibid., p. 80. 
genotype-phenotype and organism-environment dichotomies. Darwinian functionalism, they asserted, reduced organisms to collections of traits and then called upon natural selection to explain every aspect of organic form, attributing quasi-teleological creative powers to it. The true method, they argued, was to abandon the concept of biological adaptation ( $\mathrm{a}$ subset of environmental functionalism ") and explain the evolution of whole organisms in terms of structural laws, providing « explanations of the actual as realizations from a constrained set of possibilities defined by intrinsic principles of physical order ". Reductionist genetic determinism must be replaced by biological determinism at a higher level. « The absolutely fundamental question », Hughes and Lambert concluded, " is whether the real world can best be interpreted from a functionalist or a structuralist perspective $"{ }^{29}$.

Marxist biologists, on the other hand, were not content with suggesting a new "way of seeing " the facts of nature. Instead, they set out to show that the Darwinian and neo-Darwinian views of evolutionary change were reflections of bourgeois society. Darwin, said Richard Levins and Richard Lewontin in their book of essays entitled The Dialectical Biologist, performed a valuable service by substituting « real, material entities " (individual organisms and populations) for the ideal forms of species and explaining organic change by " real forces among real existing objects ". But, bourgeois Victorian that he was, Darwin was led astray by Cartesian reductionism, the prototypical scientific reflex of a social order that regarded society as a collection of individuals. Accordingly, Darwin and his followers reduced organisms to collections of traits and viewed natural selection as selecting among those traits to produce ever more perfect adaptation to an environment that changed without reference to the needs and purposes of organisms.

«It is the organism as the alienated object of external forces that marks off the Cartesianism of Darwin from the dialectical view of organism and environment as interpenetrating so that both are at the same time subjects and objects of the historical process $"{ }^{30}$.

In neo-Darwinian theory, Levins and Lewontin add, the Cartesian approach has produced a population genetics capable of describing

29. A. J. Hughes, D. M. LAmbert, « Functionalism, Structuralism, and "Ways of Seeing" ", Journal of Theoretical Biology, 3, 1984, p. 787, 789, 794-797. See also Stephen J. Gould, Richard C. Lewontin, «The Spandrels of San Marco and the Panglossian Paradigm : A Critique of the Adaptationist Programme ", Proc. Roy. Soc. Lond., B 205, 1979, p. 581-598.

30. Richard Levins, Richard C. Lewontin, The Dialectical Biologist, Cambridge, MA, Harvard University Press, 1985, p. 4. 
mathematically the endless reshuffling of the basic units of DNA but incapable of accounting for qualitative change ; an ecology that ignores the impact of organisms on their environments and imposes on nature concepts of efficiency, waste, maximum return on investment, etc. borrowed from bourgeois political economy ; and a sociobiology that reduces organisms to collections of traits and then explains those traits as determined by genes.

To replace the " mechanistic materialism " of bourgeois evolutionists Levins and Lewontin recommend Friedrich Engels' dialectical view of nature-purged, however, of its Lamarckian assumptions. In this view " motion " becomes synonymous with change, as it was for Aristotle. It comprehends « all changes and processes occurring in the universe, from mere change of place right up to thinking " ${ }^{31}$. For Levins and Lewontin, as for Spencer and Julian Huxley, " evolution " embraces cosmic and social as well as biological evolution; they are all part of the universal dialectic of nature. " Parts and wholes evolve in consequence of their relationship and the relationship itself evolves ${ }^{32}$. The "materialism " of this view seems to consist in the authors' insistence that explanations must involve only " real forces among real existing objects " (ideal entities are not " real "; individual organisms and populations are real, but whether species, genera, classes, etc. are real is not clear).

Despite their rejection of " mechanistic " materialism, Levins and Lewontin resort to the language of mechanics in describing the operation of the "forces " of natural selection arising out of the struggle for existence :

"Once it is assumed that evolutionary change is the result of the conversion of variation among individuals into variation among species and of successive alterations of species over time, it is necessary to identify the force for that conversion and to describe the mechanism by which that force converts the variation. That is, we need a dynamics and a kinematics ${ }^{33}$.

Unfortunately, these authors add, modern evolutionary theory provides only a kinematics of the evolution of abstract genotypes without any dynamics of organism-environment interaction capable of explaining the transformation of quantitative into qualitative change. Until such an « exact theory " is attained, they conclude, ideas of evolutionary order and direction must continue to be dictated by ideological commitments ${ }^{34}$.

31. Ibid., p. 11.

32. Ibid., p. 3-4, 31 .

33. Ibid., p. 31 .

34. Ibid., p. 64, 16. 
It seems evident, then, that concepts of nature and science are in flux. The ideas of nature and science Darwin and his contemporaries took for granted are no longer viable, although they linger on in the biological community as convenient sticks with which to beat creationists, finalists, and vitalists. New views of nature and science, of man and society, of reality in general are in the making. What dominant view of nature and man's place in it (clothed in appropriate figures of speech) will emerge in the twenty-first century only future historians of ideas can tell.

John C. GREENE, University of Connecticut. 